DOI: $10.29303 /$ jrpb.v9i1.176

ISSN 2301-8119, e-ISSN 2443-1354

Tersedia online di http://jrpb.unram.ac.id/

\title{
SINTESIS MINYAK KELAPA SAWIT (Elaeis guineensis) MENJADI BIODIESEL MENGGUNAKAN METIL ASETAT DENGAN METODE INTERESTERIFIKASI
}

\author{
Synthesis of Palm Oil (Elaeis guineensis) to Biodiesel using Methyl Acetate \\ with Interesterification Method
}

\author{
Sandra, Sandra ${ }^{*}$, Bambang Susilo, Nadia Ijkri Aulia \\ Jurusan Keteknikan Pertanian, Fakultas Teknologi Pertanian, Universitas Brawijaya \\ J1. Veteran, Kota Malang, 65145, Indonesia \\ Email*): sandra.msutan@ub.ac.id \\ Diterima: Desember 2020 \\ Disetujui: Maret 2021
}

\begin{abstract}
The biodiesel manufacturing process from palm oil is carried out through the transesterification method using methanol and produces a by-product of glycerol, reducing its economic value. Thus, the transesterification method was changed to the interesterification method by changing methanol to methyl acetate, which produces a by-product in triacetin. This study aims to determine the optimal condition of variation in the concentration of $1.0 \%, 1.5 \%$, and $2.0 \% \mathrm{NaOH}$ catalysts and the duration of synthesis for 3 hours and 6 hours of biodiesel characteristics by the interesterification method. The yield of biodiesel produced ranged from $40.87 \%-59.50 \%$ with viscosity characteristics of $4,807-4,848 \mathrm{~mm}^{2} / \mathrm{s}$, density values of 0.869 - $0.870 \mathrm{~g} / \mathrm{ml}$, and FAME content of 81.79 - 84.84\%. The study results are in accordance with the Indonesian National Standard (SNI) of Biodiesel, except FAME. However, the FAME content in this study still approaches the standard. Results of the analysis of variance showed that variations in the concentration of $\mathrm{NaOH}$ catalyst concentration and synthesis time did not affect yield, viscosity, density, and FAME content. Therefore, for determining the better treatment economics approach (such as processing time and cost) can be associated. The better treatment is on the 1\% NaOH catalyst and the synthesis time for 3 hours, which has a yield of $49.16 \%$ with characteristics of $4,813 \mathrm{~mm}^{2} / \mathrm{s}$ viscosity value, $0.869 \mathrm{~g} / \mathrm{ml}$ density, and $83.40 \%$ FAME content.
\end{abstract}

Keywords: biodiesel; crude palm oil; interesterification; methyl acetate

\begin{abstract}
ABSTRAK
Pembuatan biodiesel dari minyak kelapa sawit dilakukan melalui metode transesterifikasi menggunakan metanol dan menghasilkan hasil samping berupa gliserol yang dapat mengurangi nilai ekonominya. Oleh karena itu, metode transesterifikasi digantikan menjadi metode interesterifikasi dengan mengubah metanol menjadi metil asetat yang menghasilkan hasil samping berupa triasetin. Penelitian ini bertujuan untuk mengetahui kondisi optimal dari variasi konsentrasi katalis $\mathrm{NaOH} 1,0 \%, 1,5 \%$, dan 2,0\% dan lama waktu sintesis selama 3 jam dan 6 jam terhadap karakteristik biodiesel dengan metode interesterifikasi. Rendemen biodiesel
\end{abstract}


yang dihasilkan berkisar antara 40,87\% - 59,50\% dengan karakteristik viskositas 4,807 - 4,848 $\mathrm{mm}^{2} / \mathrm{s}$, nilai densitas $0,869-0,870 \mathrm{~g} / \mathrm{ml}$, dan kandungan FAME 81,79\% - 84,84\%. Hasil penelitian telah sesuai dengan Standar Nasional Indonesia (SNI) Biodiesel, kecuali FAME. Namun, kandungan FAME pada penelitian ini masih mendekati standar. Hasil analisis sidik ragam menunjukkan adanya perlakuan variasi konsentrasi katalis $\mathrm{NaOH}$ dan waktu sintesis yang tidak memiliki pengaruh terhadap rendemen, viskositas, densitas, dan kandungan FAME. Dengan demikian dalam menentukan perlakuan yang lebih baik dapat dikaitkan dengan keekonomisan (seperti waktu proses dan biaya). Perlakuan yang lebih baik adalah pada katalis $\mathrm{NaOH}$ 1\% dan waktu sintesis selama 3 jam, dimana memiliki rendemen 49,16\% dengan karakteristik yang memiliki nilai viskositas $4,813 \mathrm{~mm}^{2} / \mathrm{s}$, densitas $0,869 \mathrm{~g} / \mathrm{ml}$, dan kandungan FAME $83,40 \%$.

Kata kunci: biodiesel; crude palm oil; interesterifikasi; metil asetat

\section{PENDAHULUAN}

\section{Latar Belakang}

Penggunaan sumber energi di Indonesia masih didominasi oleh bahan bakar minyak (BBM). Bahan baku BBM adalah minyak bumi yang berasal dari proses penguraian organisme tumbuhan dan hewan berukuran sangat kecil (plankton) yang mati dan terkubur di lautan purba jutaan tahun yang lalu sehingga bersifat tidak dapat diperbaharui. Menurut Bappenas (2018), jumlah penduduk Indonesia di tahun 2019 diproyeksikan mencapai 266,91 juta jiwa yang terdiri atas 134 juta jiwa laki-laki dan 132,89 juta jiwa perempuan. Jumlah tersebut mengalami peningkatan jika dibandingkan pada tahun 2018 dengan jumlah penduduk sebesar 265 juta jiwa. Peningkatan tersebut berpengaruh terhadap penggunaan sumber energi di Indonesia. Hal ini dikarenakan tingginya angka penduduk di Indonesia juga mempengaruhi peningkatan jumlah kendaraan guna mendukung terdistribusinya barang (produk) dan jasa ke berbagai kota maupun pelosok daerah. Oleh karena itu, dibutuhkan sumber daya energi alternatif yaitu biodiesel.

Biodiesel adalah salah satu bahan bakar alternatif yang ramah lingkungan. Sintesis biodiesel telah banyak dilakukan dengan memakai berbagai macam minyak nabati, salah satunya adalah minyak kelapa sawit (Crude Palm Oil). Proses pembuatan biodiesel dari minyak kelapa sawit dilakukan melalui reaksi transesterifikasi dengan menggunakan alkohol. Namun, metode tersebut menghasilkan hasil samping berupa gliserol yang dapat mengurangi nilai ekonominya. Selain itu, adanya penggunaan alkohol memiliki kelemahan yaitu proses pemurnian produk yang bercampur secara homogen, sehingga sulit untuk dipisahkan. Serta apabila alkohol bereaksi dengan trigliserida dapat terjadi reaksi samping, yaitu saponifikasi atau reaksi penyabunan yang mengakibatkan proses pemisahan produk semakin sulit. Oleh karena itu, pada penelitian kali ini digunakan metode interesterifikasi dengan menggunakan metil asetat sebagai pendonor alkil. Hal ini dikarenakan pada metode interesterifikasi dapat menghindari teknik pemurnian dan pemisahan yang kompleks, sehingga memiliki kelebihan dibandingkan metode transesterifikasi. Selain itu, produk samping dari proses interesterifikasi ini menghasilkan triasetin yang memiliki nilai jual lebih tinggi dibandingkan gliserol. Triasetin memiliki fungsi sebagai bahan aditif dalam industri pabrik baik di bidang makanan, farmasi, maupun kosmetik. Terdapat 3 tahap pembentukan triasetin beserta fatty acid methyl ester (FAME)-nya yaitu dimulai dari trigliserida direaksikan menggunakan metil asetat sehingga terbentuk monoacetindigliserida (MADG), lalu MADG direaksikan lagi menggunakan metil asetat sehingga terbentuk diacetinmonogliserida (DAMG). Kemudian DAMG direaksikan lagi menggunakan metil 
asetat sehingga terbentuk triasetin dan FAME.

Treatment dalam mengkonversi minyak kelapa sawit menjadi biodiesel telah dilakukan oleh Hermansyah, et al., (2009). Penelitian tersebut menggunakan biokatalis berupa enzim candida rugosa lipase dan telah berhasil menghasilkan yield biodiesel sebesar $86,55 \%$. Namun, penggunaan enzim sebagai biokatalis memiliki kelemahan, yaitu harga yang relatif mahal, hanya dapat dipakai untuk satu kali reaksi, ketidakstabilan enzim, dan ketersediaan enzim yang sangat sedikit (Setyahadi, et al., 2011). Jenis katalis yang digunakan pada penelitian ini adalah $\mathrm{NaOH}$, karena $\mathrm{NaOH}$ dapat digunakan pada suhu dan tekanan operasi yang relatif rendah serta memiliki kemampuan katalisator yang tinggi. Terdapat 4 tahap dalam melakukan penelitian ini, yaitu pembuatan larutan metil asetat, pelarutan $\mathrm{NaOH}$ ke dalam metil asetat, interesterifikasi, dan pemurnian hasil interesterifikasi. Setelah dilakukan tahapan tersebut, dilakukan uji analisis berupa nilai rendemen, viskositas, densitas, dan FAME.

\section{Tujuan}

Tujuan dari penelitian ini adalah menganalisis karakteristik biodiesel hasil sintesis minyak kelapa sawit menggunakan metil asetat sebagai pensuplai gugus metil pengganti methanol dengan metode interesterifikasi dan mencari perlakuan terbaik.

\section{METODE PENELITIAN}

\section{Waktu dan Tempat Penelitian}

Penelitian ini dilakukan pada bulan Oktober hingga Desember 2019 di Laboratorium Biologi Dasar, Fakultas Teknologi Pertanian, Universitas Brawijaya (untuk proses pengolahan biodiesel dan uji rendemen) dan Laboratorium Kimia Analisis dan Instrumentasi, Jurusan Teknik Kimia, Politeknik Negeri Malang (untuk pengujian viskositas, densitas, dan kandungan FAME).

\begin{abstract}
Alat dan Bahan
Peralatan yang digunakan dalam penelitian ini adalah: waterbath shaker (Julabo SW22), gelas ukur $(100 \mathrm{ml})$, erlenmeyer $(250 \mathrm{~mL})$, aluminium foil, neraca analitik, corong, hotplate stirrer, stopwatch, corong pisah $(250 \mathrm{~mL})$, gelas arloji, mortar dan alu, spatula, pipet tetes, dan botol kaca. Selain itu, bahan yang digunakan dalam penelitian ini adalah minyak sawit, $\mathrm{NaOH}$, metil asetat, dan aquades.
\end{abstract}

\section{Metode Pengolahan Data}

Rancangan percobaan penelitian menggunakan metode Rancang Acak Lengkap (RAL) dengan 2 (dua) faktor yaitu variasi konsentrasi katalis $\mathrm{NaOH}(1,0 \%$, $1,5 \%, 2,0 \%)$ dan variasi waktu sintesis (3 jam dan 6 jam) dengan 3 (tiga) kali pengulangan, sehingga total unit percobaan sebanyak 18 (delapan belas). Metode RAL dianalisis menggunakan ANOVA (analysis of variances). Kemudian, hasil tersebut, apabila berpengaruh nyata, maka akan diuji lanjut dengan uji Duncan pada tingkat signifikansi $\alpha=5 \%$. Lalu, data yang didapatkan dibandingkan dengan mutu biodiesel pada SNI 7182:2015. Variabel yang diamati dalam penelitian ini adalah rendemen, viskositas kinematik, densitas, dan kandungan FAME.

\section{HASIL DAN PEMBAHASAN}

Penelitian ini menghasilkan biodiesel yang memiliki warna kuning, jernih, dan encer seperti pada Gambar 1. Warna biodiesel memiliki warna yang lebih cerah dibandingkan minyak sawit pada Gambar 2. Hal ini dikarenakan hasil reaksi dengan pelarut organik yaitu metil asetat. Adapun untuk hasil samping pada reaksi interesterifikasi adalah triasetin yang memiliki warna putih keruh seperti pada Gambar 3. Triasetin dapat dimanfaatkan sebagai bahan aditif dalam industri pabrik makanan (pelarut dalam perasa dan penambah aroma), farmasi (eksifien dalam produk farmasi dimana digunakan sebagai 
humektan, plastisizer, dan pelarut), dan kosmetik (sebagai bahan pelapis yang berfungsi agar kosmetik tidak mudah luntur dan pudar jika terkena gesekan).

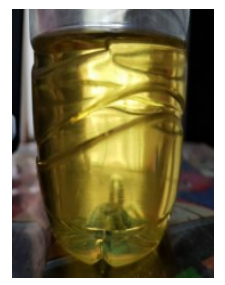

Gambar 1.

Minyak

Sawit

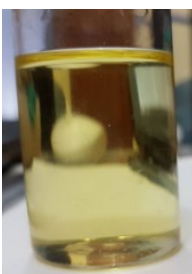

Gambar 2.

Biodiesel

Minyak

Sawit

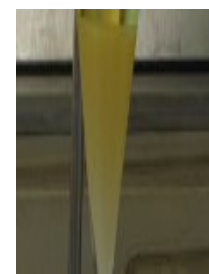

Gambar 3.

Triasetin

\section{Rendemen Biodiesel}

Pengujian nilai rendemen pada biodiesel dilakukan dengan cara menghitung perbandingan antara massa biodiesel yang dihasilkan terhadap bahan baku minyak sawit awal dan kemudian dikalikan $100 \%$. Pada hasil penelitian ini, didapatkan nilai rendemen yang berkisar antara 40,87\% hingga 59,50\%. Grafik rendemen biodiesel minyak sawit dapat dilihat pada Gambar 4.

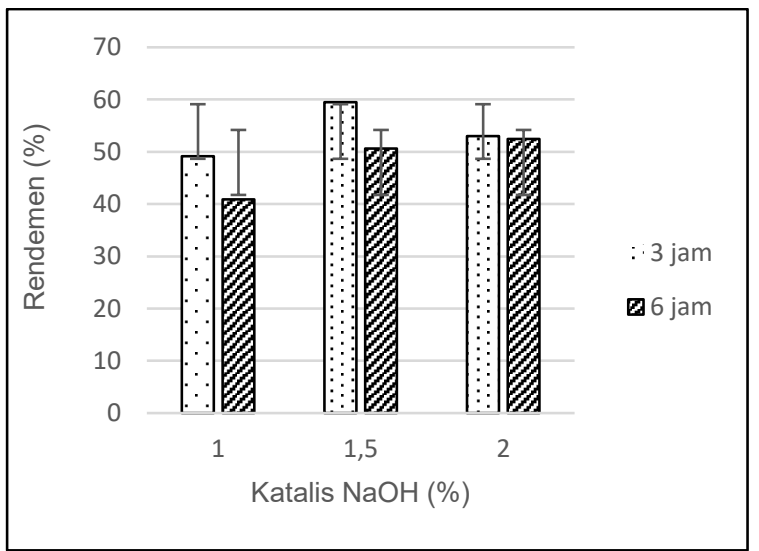

Gambar 4. Rendemen biodiesel minyak sawit

Berdasarkan Gambar 4, terlihat waktu sintesis 3 jam konsentrasi $1,5 \%$ memiliki rendeman yang paling besar. Hal ini disebabkan karena katalis $1,5 \%$ adalah katalis optimal. Katalis yang lebih tinggi konsentrasinya akan menyebabkan terbentuknya dimetil eter antara metanol dan $\mathrm{NaOH}$. Pada waktu katalis 6 jam terlihat semakin tinggi konsentrasi, rendemen semakin tinggi. Sedangkan pada waktu sintesis 3 jam dari konsentrasi 1\%, rendemennya naik untuk konsentrasi $1,5 \%$, sesudah itu turun lagi (2\%). Karena semakin tinggi konsentrasi $\mathrm{NaOH}$, semakin cepat reaksi berlangsung. Akan tetapi saat konsentrasi katalis $2 \%$, selain terbentuk dimetil eter, $\mathrm{NaOH}$ juga akan terbawa dalam lapisan organik, sehingga asam lemak bebas akan bereaksi dengan $\mathrm{NaOH}$ yang berlebih dan membentuk reaksi saponifikasi yang menghambat terbentuknya metil ester. Hasil yang mirip juga terdapat pada penelitian Hartono, et al., (2013) dimana rendemen metil ester dari CPO kadar rendah dengan rasio katalis $\mathrm{NaOH}$. Semakin besar hasil, semakin banyak produk yang didapat. Rasio katalis $\mathrm{NaOH} 0,5 \%$ diperoleh rendemen produk 54,8\%, sedangkan untuk rasio katalis sebesar $1 \%$ diperoleh rendemen produk $60,8 \%$ dan untuk rasio katalis sebanyak $1,5 \%$ diperoleh rendemen produk $51,2 \%$.

Secara keseluruhan, dapat dilihat bahwa pada waktu sintesis selama 3 jam memiliki nilai rendemen yang lebih tinggi dibandingkan dengan waktu sintesis selama 6 jam. Jika dibandingkan dari penelitian Hermansyah, et al., (2009) yang menghasilkan rendemen sebesar 86,55\%, maka rendemen yang dihasilkan pada penelitian ini memiliki nilai yang lebih rendah, tetapi lebih tinggi dari penelitian Pristiyani \& Kusumaningtyas (2015) yang hanya menghasilkan rendemen sebesar $13,79 \%$. Waktu yang digunakan pada penelitian ini cukup lama dibandingkan pengolahan biodiesel menggunakan gelombang ultrasonik. Susilo, et al., (2009) menyatakan bahwa cukup dengan waktu 0,5 - 7 menit, konversi maksimum trigliserida menjadi ester dan gliserol (menggunakan reaksi transesterifikasi) sudah terjadi diantara selang waktu proses tersebut. Sehingga, waktu pada penelitian ini kurang efektif untuk digunakan. Proses interesterifikasi pada penelitian ini dapat dilakukan dengan menggunakan gelombang ultrasonik, agar hanya membutuhkan waktu yang singkat untuk sintesis. 
Hasil analisis sidik ragam menunjukkan bahwa variasi konsentrasi katalis, lama waktu sintesis tidak berpengaruh nyata terhadap nilai rendemen biodiesel, dan tidak ada interaksi kedua perlakuan dimana F-hitung vs F-tabel katalis 1,626 vs 3,89 ; waktu 0,15 vs 4,75 dan interaksi perlakuan 0,32 vs 3,89 . Tidak adanya pengaruh tersebut memiliki arti bahwa semua perlakuan memiliki pengaruh yang sama terhadap hasil. Hal ini dikarenakan nilai rendemen lebih dipengaruhi oleh kecepatan pengadukan dan suhu reaksi, dimana semakin tinggi kecepatan pengadukan dan suhu reaksi, semakin meningkat rendemen biodiesel (Kartika, et al. 2011). Selain itu, dalam menentukan perlakuan yang lebih baik dapat dikaitkan dengan keekonomisan (seperti waktu proses dan biaya), dimana dengan waktu sintesis selama 3 jam dan katalis $\mathrm{NaOH} 1,0 \%$ memiliki waktu proses yang lebih rendah dibanding perlakuan dengan waktu sintesis selama 6 jam, serta biaya yang lebih murah akibat penggunaan katalis yang lebih sedikit dan penggunaan alat yang lebih cepat.

\section{Viskositas biodiesel}

Viskositas merupakan salah satu sifat fisik biodiesel yang cukup penting. Pengujian viskositas dilakukan untuk mengetahui tingkat kekentalan biodiesel. Grafik viskositas kinematik pada biodiesel minyak sawit dapat dilihat pada Gambar 5.

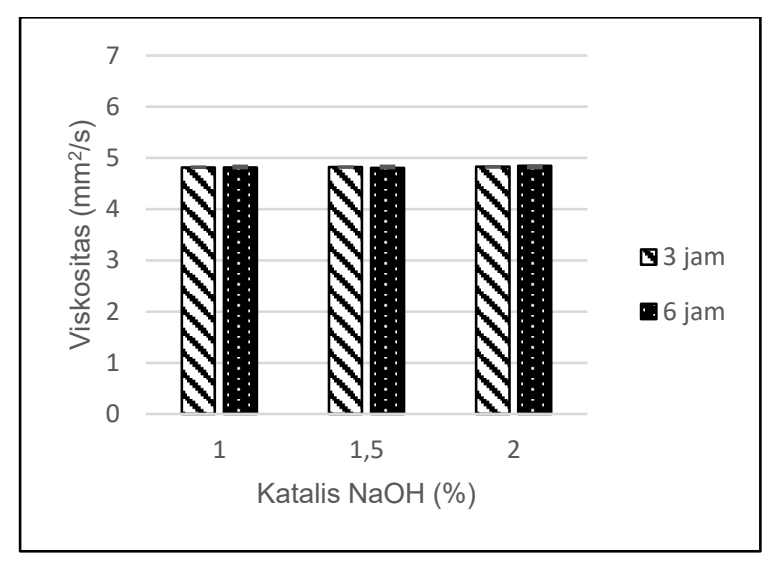

Gambar 5. Viskositas pada biodiesel minyak sawit
Pada Gambar 5 terlihat waktu sintesis selama 3 jam memiliki nilai viskositas yang semakin meningkat dengan meningkatnya jumlah atau konsentrasi katalis dari 4,813 untuk katalis $1 \%$, 4,82 untuk katalis $1,5 \%$ dan 8,83 untuk katalis 2\%. Hal ini sesuai dengan penelitian sebelumnya (Hidayati, et al., 2017), dimana peningkatan jumlah katalis dalam suatu campuran reaksi dapat menyebabkan peningkatan viskositas. Waktu sintesis selama 3 jam memiliki nilai yang relatif lebih rendah dibandingkan waktu selama 6 jam. Hal ini disebabkan karena adanya komponen gliserida yang belum terkonversi menjadi FAME, sehingga menyebabkan nilai viskositas yang masih tinggi.

Viskositas biodiesel yang dihasilkan pada semua perlakuan (kisaran rata-rata 4,82-4,85 $\mathrm{mm}^{2} / \mathrm{s}$ ) telah memenuhi Standar Nasional Indonesia yang mensyaratkan viskositas berkisar antara 2,3-6,0 $\mathrm{mm}^{2} / \mathrm{s}$. Selain menggunakan Standar Nasional Indonesia (SNI), juga dapat menggunakan standar Internasional $\left(3,5-5,0 \quad \mathrm{~mm}^{2} / \mathrm{s}\right)$ dimana hasil viskositas ini telah sesuai dengan standar tersebut. Apabila viskositas terlalu rendah, maka akan menyebabkan kebocoran dalam pompa injeksi bahan bakar. Hasil yang diperoleh pada penelitian ini memiliki nilai lebih tinggi jika dibandingkan dengan penelitian sebelumnya. Pada penelitian ini, hasil viskositas yang didapatkan mencapai 4,848 $\mathrm{mm}^{2} / \mathrm{s}$, dimana nilai tersebut masih terlalu encer meskipun sesuai dengan SNI. Adanya perbedaan disebabkan oleh faktor rasio reaktan, dimana penelitian lain menggunakan rasio reaktan 1:12. Hal ini dikarenakan volume yang sangat banyak dari metil asetat akan membuat biodiesel semakin encer sehingga akan menurunkan nilai viskositas biodiesel. Tidak hanya rasio reaktan, tetapi faktor lain yang dapat mempengaruhi viskositas adalah jenis minyak. Pada penelitian Hartono, et al., (2013) dihasilkan viskositas biodiesel sebesar $7,24 \mathrm{~mm}^{2} / \mathrm{s}$, dengan bahan minyak jelantah, dimana minyak jelantah memiliki free fatty acid (FFA) yang lebih tinggi 
dibanding FFA minyak sawit. Semakin tinggi FFA suatu minyak, maka semakin kental minyak tersebut.

Hasil analisis sidik ragam menunjukkan bahwa kedua perlakuan tidak berpengaruh nyata terhadap nilai viskositas biodiesel dan tidak ada interaksi antara kedua perlakuan ( $\mathrm{F}$ hitung 0,167 $<\mathrm{F}$ tabel 3,89). Nilai viskositas lebih dipengaruhi oleh kandungan trigliserida yang tidak bereaksi dengan metil asetat, komposisi asam lemak penyusun metil ester biodiesel, serta senyawa intermediet seperti monogliserida dan digliserida yang memiliki polaritas dan bobot molekul yang cukup tinggi. Viskositas akan meningkat seiring dengan panjangnya rantai asam lemak yang dimiliki biodiesel. Dalam menentukan perlakuan yang lebih baik dapat dikaitkan dengan keekonomisan (seperti waktu proses dan biaya), dimana dengan waktu sintesis selama 3 jam dan katalis $\mathrm{NaOH} 1,0 \%$ memiliki waktu proses yang lebih rendah dibanding perlakuan dengan waktu sintesis selama 6 jam. Selain itu, biaya proses pada penelitian ini lebih murah akibat penggunaan katalis yang lebih sedikit dan penggunaan alat yang lebih cepat. Artinya biaya yang dikeluarkan lebih sedikit untuk membeli katalis dan waktu yang digunakan juga lebih cepat (setengahnya 3 jam : 6 jam).

\section{Densitas biodiesel}

Uji densitas dilakukan pada suhu $40^{\circ} \mathrm{C}$ (sesuai parameter uji SNI 7182:2015 tentang syarat mutu biodiesel). Grafik densitas biodiesel minyak sawit seperti diperlihatkan pada Gambar 6.

Pada Gambar 6 terlihat waktu sintesis selama 3 jam memiliki nilai densitas yang semakin meningkat dengan meningkatnya jumlah atau konsentrasi katalis (mulai dari $\mathrm{NaOH} 1,0 \%$ hingga $\mathrm{NaOH} 1,5 \%$ (masingmasing 0,869667 ke $0,870000 \mathrm{~g} / \mathrm{ml}$ ), terdapat nilai yang konstan ketika konsentrasi $\mathrm{NaOH}$ dari 1,5\% ke NaOH 2,0\% yaitu $0,87 \mathrm{~g} / \mathrm{ml}$. Pada waktu sintesis selama 6 jam memiliki nilai densitas yang sama untuk konsentrasi $\mathrm{NaOH} 1 \%$ dan 1,5\%,
$(0,869667 \mathrm{~g} / \mathrm{ml})$ kemudian, mengalami peningkatan pada pada saat penambahan jumlah konsentrasi $\mathrm{NaOH}$ menjadi 2,0\%, menjadi $0,87 \mathrm{~g} / \mathrm{ml}$. Peningkatan nilai densitas dengan meningkatnya jumlah katalis dan lamanya waktu sintesis disebabkan semakin lama waktu sentesis, biodiesel akan semakin encer. Hal ini sama dengan penelitian dari Faizal, et al. (2013) yang menyatakan bahwa semakin banyak jumlah katalis yang digunakan pada pembuatan biodiesel, maka semakin besar densitas dari suatu produk biodisel yang dihasilkan.

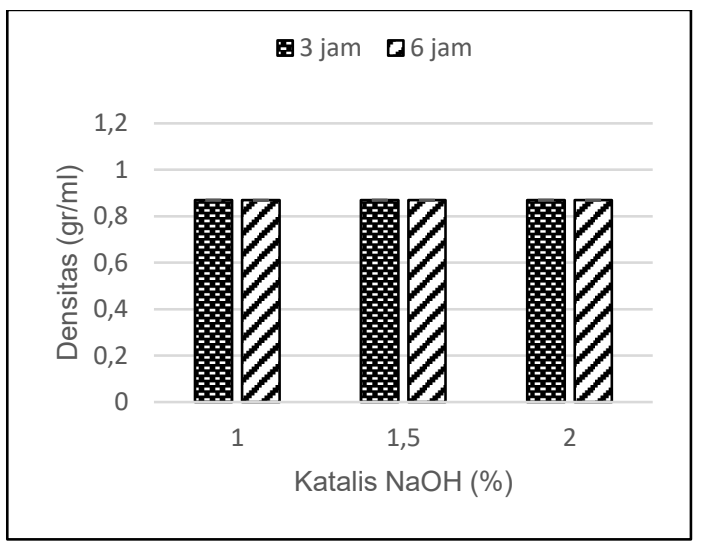

Gambar 6. Densitas pada biodiesel minyak sawit

Densitas yang dihasilkan pada penelitian ini telah memenuhi Standar Nasional Indonesia yaitu $0,85-0,89 \mathrm{~g} / \mathrm{ml}$. Selain menggunakan Standar Nasional Indonesia (SNI), juga dapat menggunakan standar Internasional dimana hasil densitas ini telah sesuai dengan standar tersebut (Jerman 0,875-0,9 g/ml; Italia 0,86-0,9 g/ml Europe 0,86-0,9 g/ml). Apabila densitas biodiesel yang dihasilkan tidak memenuhi standar maka dapat menyebabkan kerusakan mesin, dimana terjadi peningkatan keausan pada mesin dan emisi buangan. Jika dibandingkan dengan densitas dari bahan baku yang digunakan, yaitu minyak sawit sebesar $0,875 \mathrm{~g} / \mathrm{ml}$, maka terdapat penurunan densitas yang dihasilkan. Penurunan ini dipengaruhi oleh tahap pemurnian karena tahap pemurnian yang kurang baik yang dapat menyebabkan 
biodiesel memiliki densitas yang bervariasi (Purwaningrum \& Sukaryo, 2018).

Hasil analisis sidik ragam menunjukkan bahwa variasi konsentrasi tidak berpengaruh nyata terhadap nilai densitas biodiesel dan tidak ada interaksi kedua perlakuan ( $\mathrm{F}$ hitung $0,449<\mathrm{F}$ tabel 3,89). Menurut teori termodinamika, nilai densitas lebih dipengaruhi oleh suhu. Semakin tinggi suhu suatu fluida, maka molekul fluida, yang dalam hal ini adalah molekul reaktan berupa minyak sawit dan metil asetat, akan bergerak lebih cepat atau energi kinetik yang dimiliki molekulmolekul pereaksi semakin besar. Pergerakan molekul yang lebih cepat ini menyebabkan peregangan pada jarak antar molekulnya sehingga semakin melebar atau semakin meningkat tumbukan antara molekul pereaksi. Pelebaran tersebut menyebabkan jarak antar molekul yang lebar akan mengakibatkan densitas menurun (Hartono, et al., 2013). Dalam menentukan perlakuan yang lebih baik dapat dikaitkan dengan keekonomisan (seperti waktu proses dan biaya). Waktu sintesis selama 3 jam dan katalis $\mathrm{NaOH} 1,0 \%$ memiliki waktu proses yang lebih rendah dibanding perlakuan dengan waktu sintesis selama 6 jam, serta biaya yang lebih murah akibat penggunaan katalis yang lebih sedikit.

\section{Kandungan FAME}

Metil ester minyak sawit yang telah dianalisis dengan GC (Gas chromatography) rata-rata menunjukkan empat sampai lima puncak yang sama seperti pada Gambar 7, Gambar 8, dan Gambar 9. Sampel yang dianalisis secara kromatogram adalah perlakuan terbaik dilihat dari keekonomisan (seperti waktu proses dan biaya), yaitu perlakuan konsentrasi katalis $1,0 \%$ dan waktu sintesis 3 jam.

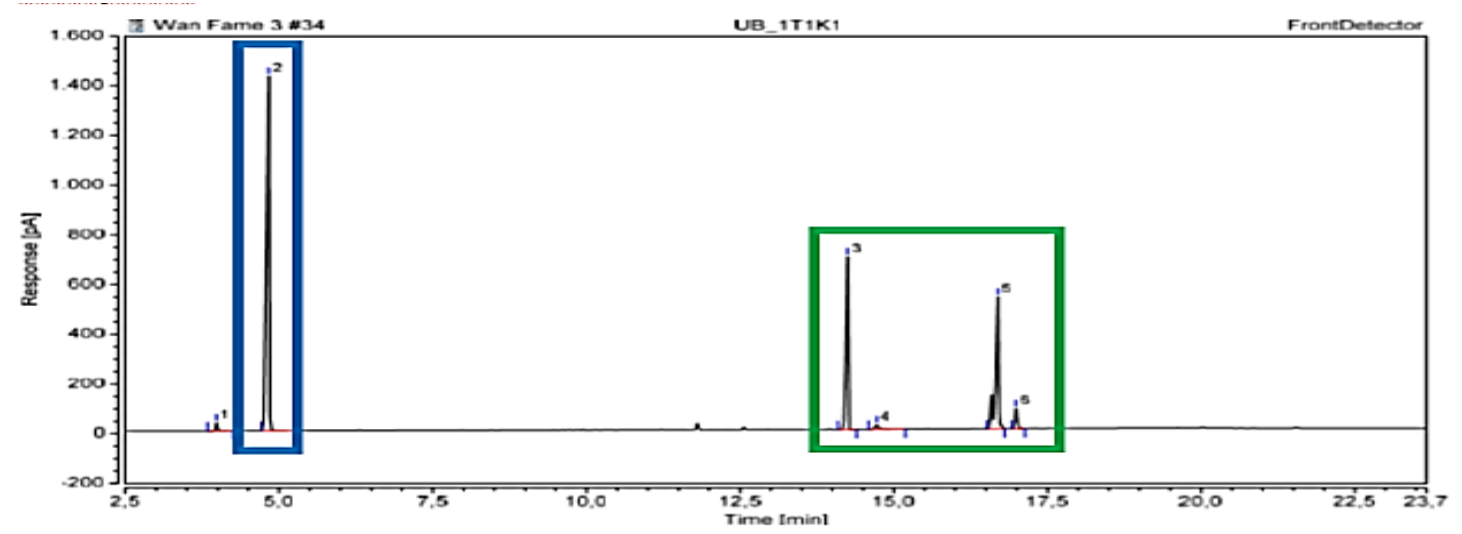

Gambar 7. Grafik kromatogram FAME biodiesel minyak sawit dengan konsentrasi katalis 1,0\% dan waktu sintesis 3 jam pada ulangan 1

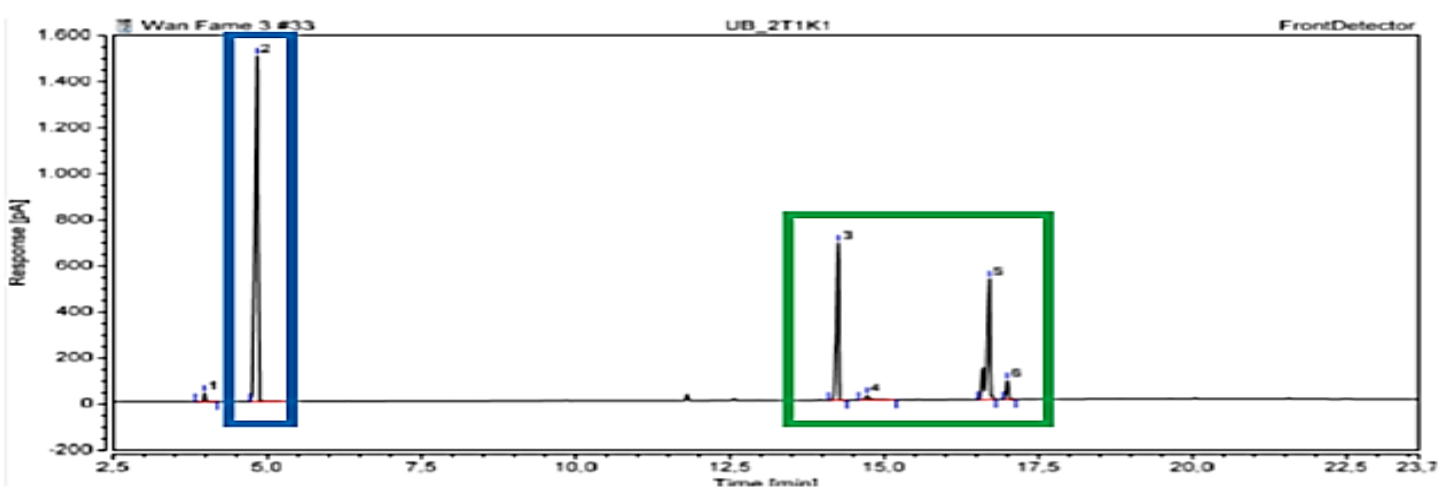

Gambar 8. Grafik kromatogram FAME biodiesel minyak sawit dengan konsentrasi katalis 1,0\% dan waktu sintesis 3 jam pada ulangan 2 


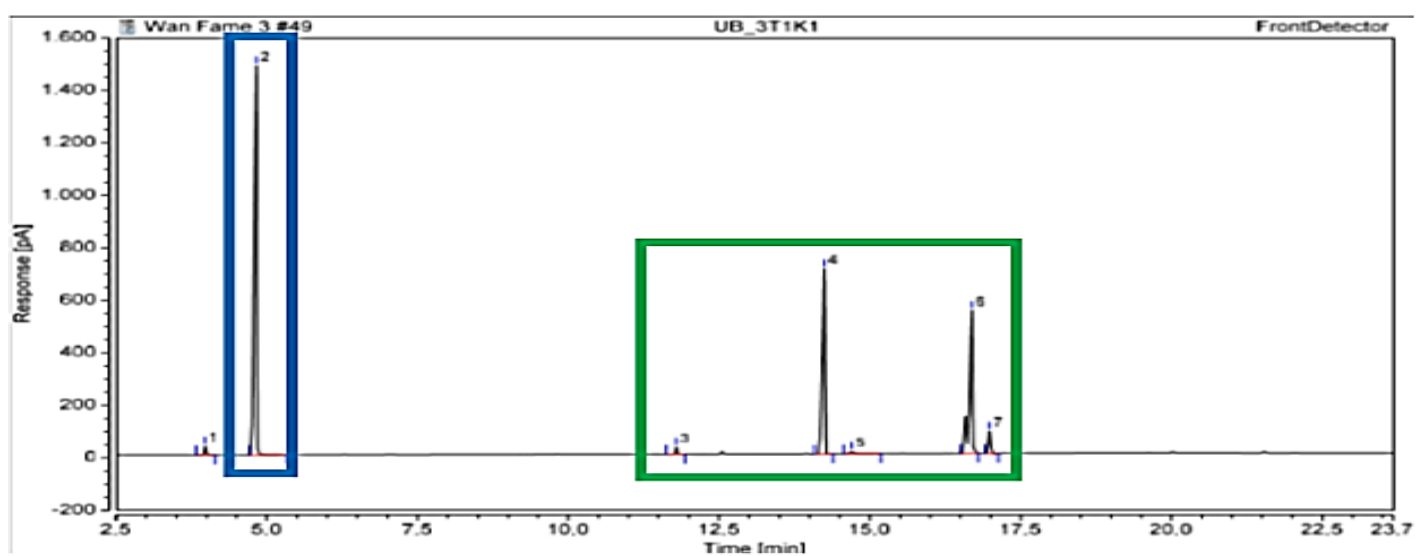

Gambar 9. Grafik kromatogram FAME biodiesel minyak sawit dengan konsentrasi katalis 1,0\% dan waktu sintesis 3 jam pada ulangan 3

Berdasarkan hasil ulangan pengukuran persentase metil ester baik pada ulangan 1, ulangan 2, maupun ulangan 3 terdapat keseragaman yang baik. Hal ini menunjukkan bahwa sampel uji mendapatkan perlakuan yang hampir seragam selama proses penelitian berlangsung. Umami (2015) menyatakan bahwa bahan baku biodiesel dengan komposisi minyak sawit mengandung asam lemak yang dominan dalam minyak sawit adalah asam palmitat (C16:0). Dengan demikian dapat diduga bahwa jenis senyawa metil ester dengan persentase tinggi (peak tertinggi) yang terdapat pada biodiesel adalah metil ester palmitat. Terdapat dua puncak yang paling awal pada sebelah kiri (kotak biru) yang merupakan puncak untuk larutan standar pada pengukuran dengan menggunakan larutan benzyl alkohol (BZ$\mathrm{OH}$ ), sedangkan puncak-puncak pada sebelah kanan (kotak hijau) adalah metil ester yang terkandung di dalam biodiesel. Semakin ke kanan peak, maka membuktikan bahwa jenis senyawa metil ester yang terkandung dalam biodiesel memiliki nilai titik didih yang semakin tinggi. Sedangkan semakin ke kiri peak, maka membuktikan bahwa jenis senyawa metil ester yang terkandung dalam biodiesel memiliki nilai titik didih yang semakin rendah.

Kandungan FAME pada biodiesel minyak sawit menunjukkan bahwa $81,79 \%$ sampai $84,84 \%$ rantai asam lemak dari trigliserida minyak sawit terkonversi menjadi ester (biodiesel). Grafik kandungan
FAME pada biodiesel minyak sawit seperti diperlihatkan pada Gambar 10.

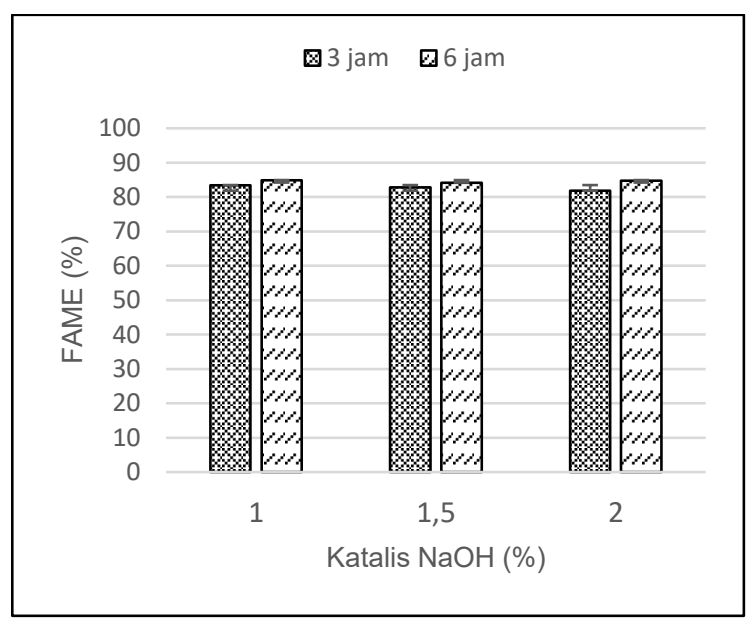

Gambar 10. Kandungan FAME pada biodiesel minyak sawit

Berdasarkan Gambar 10, pada waktu sintesis selama 3 jam memiliki kandungan FAME yang semakin menurun dengan meningkatnya jumlah atau konsentrasi katalis (dari 83,4\%, 82,81\% 81,79\% masing-masing untuk katalis $1 \%, 1,5 \%$ dan $2 \%$ ). Hal ini disebabkan karena adanya proses pengadukan (shaker) yang belum maksimum. Menurut Andwika, et al., (2016) menyatakan bahwa proses pengadukan yang secara merata akan menghasilkan jumlah dan kualitas biodiesel yang optimum dari minyak sawit. Dimana semakin tinggi kualitas biodiesel, maka kandungan FAME akan semakin tinggi. Lalu, pada waktu sintesis selama 6 jam memiliki penurunan kandungan FAME pada konsentrasi katalis $\mathrm{NaOH} 1,0 \%$ ke 
$\mathrm{NaOH} 1,5 \%$ dan mengalami peningkatan kembali pada konsentrasi katalis $\mathrm{NaOH}$ 2,0\% (masing-masing 84,84\%; 84,16\% dan $84,73 \%$ ). Adanya penurunan ini diakibatkan oleh munculnya reaksi samping antara katalis $\mathrm{NaOH}$ dengan minyak (reaksi saponifikasi) yang menyebabkan hasil penyabunan berupa surfaktan yang menghalangi kontak antara minyak dengan metil asetat. Hal ini menyebabkan kecepatan reaksi dan konversi metil ester yang dihasilkan menurun. FAME yang dihasilkan belum memenuhi Standar Nasional Indonesia dimana nilai FAME disyaratkan minimal sebesar $96,5 \%$. Namun, nilai yang dihasilkan dari penelitian ini telah mendekati standar.

Selain itu, grafik pada Gambar 10 menunjukkan bahwa waktu reaksi selama 6 jam memiliki konversi metil ester lebih besar dibandingkan waktu reaksi selama 3 jam. Hal ini sesuai dengan literatur yang mengatakan bahwa semakin lama waktu reaksi untuk mensintesis biodiesel maka laju pembentukan ke arah produk yang dihasilkan akan menjadi semakin besar (Rizkiyadi, 2008). Hasil yang diperoleh memiliki nilai lebih tinggi jika dibandingkan dengan penelitian sebelumnya. Jika pada penelitian ini hasil FAME yang didapatkan mencapai $84,84 \%$, maka pada penelitian Casas, et al., (2011) didapatkan hasil FAME yang lebih rendah, yaitu $76,7 \%$. Hal ini disebabkan karena beberapa faktor diantaranya jenis minyak yang digunakan, rasio reaktan, suhu reaksi, dan jenis katalis.

Hasil analisis sidik ragam menunjukkan bahwa variasi konsentrasi katalis tidak berpengaruh nyata terhadap nilai kandungan FAME biodiesel. Dalam menentukan perlakuan yang lebih baik dapat dikaitkan dengan keekonomisan (seperti waktu proses dan biaya). Dimana dengan waktu sintesis selama 3 jam dan katalis $\mathrm{NaOH} 1,0 \%$ memiliki waktu proses yang lebih rendah dibanding perlakuan dengan waktu sintesis selama 6 jam, serta biaya yang lebih murah akibat penggunaan katalis yang lebih sedikit dan penggunaan alat yang lebih cepat.

\section{KESIMPULAN DAN SARAN}

\section{Kesimpulan}

Rendemen yang diperoleh pada penelitian ini berkisar 40,87\% - 59,50\% dengan karakterisitik biodiesel seperti nilai viskositas antara $4,807 \mathrm{~mm}^{2} / \mathrm{s}-4,848$ $\mathrm{mm}^{2} / \mathrm{s}$, nilai densitas antara $0,869 \mathrm{~g} / \mathrm{ml} \mathrm{-}$ $0,870 \mathrm{~g} / \mathrm{ml}$, dan kandungan FAME antara $81,79 \%-84,84 \%$. Perlakuan yang lebih baik pada proses penelitian ini adalah pada katalis $\mathrm{NaOH} 1,0 \%$ dan waktu sintesis selama 3 jam, dilihat dari rendemen sebesar $49,16 \%$, nilai viskositas sebesar 4,813 $\mathrm{mm}^{2} / \mathrm{s}$, densitas sebesar $0,869 \mathrm{~g} / \mathrm{ml}$, dan FAME sebesar $83,40 \%$.

\section{Saran}

Perlu adanya netralisir setelah berlangsungnya proses interesterifikasi, perlu dilakukan pengujian lebih lanjut mengenai kandungan trigliserida, digliserida, dan monogliserida serta variasi jenis katalis untuk mengetahui jenis katalis yang sangat berpengaruh terhadap metode interesterifikasi. Metode interesterifikasi juga dapat dilakukan menggunakan gelombang ultrasonik.

\section{DAFTAR REFERENSI}

Andwika, R., Ramli, \& Mahrizal. (2016). Optimasi kecepatan putar pengadukan dan waktu pengadukan terhadap kualitas fisika biodiesel dari minyak kelapa. Pillar of Physics, 7, 89-96.

Bappenas. (2018). Laporan Kinerja Kementerian PPN/Bappenas Tahun 2018 (Bappenas (ed.)). Kementerian PPN/Bappenas.

Casas, A., Ramos, M. J., \& Pérez, Á. (2011). New trends in biodiesel production: chemical interesterification of sunflower oil with methyl acetate. In Biomass and Bioenergy, 35(5), 17021709.

https://doi.org/10.1016/j.biombioe.201 1.01 .003 
Faizal, M., Maftuchah, U., \& Auriyani, W. A. (2013). Pengaruh Kadar Metanol, Jumlah Katalis, Dan Waktu Reaksi Pada Pembuatan Biodiesel Dari Lemak Sapi Melalui Proses Transesterifikasi. Jurnal Teknik Kimia, 19(4), 29-37.

Hartono, R., Listiadi, A. P., \& Bayupramana, I. (2013). Intensifikasi Biodiesel dari Minyak Jelantah dengan Metode Interesterifikasi dan Pemurnian Dry Washing. Jurnal Teknologi Pengelolaan Limbah, 16(3), 49-56.

Hermansyah, H., Marno, S., Arbianti, R., Utami, T. S., \& Wijanarko, A. (2009). Interesterifikasi Minyak Kelapa Sawit Dengan Terimobilisasi. Jurnal Teknik Kimia Indonesia, 8(1), 24-32.

Hidayati, N., Ariyanto, T. S., \& Septiawan, H. (2017). Transesterifikasi Minyak Goreng Bekas Menjadi Biodiesel Dengan Katalis Kalsium Oksida. Jurnal Teknologi Bahan Alam, 1(1), 15.

Kartika, I. A., Yani. M \& Hermawan, D. (2011). Transesterifikasi In Situ Biji Jarak Pagar: Pengaruh Jenis Pereaksi, Kecepatan Pengadukan Dan Suhu Reaksi Terhadap Rendemen Dan Kualitas Biodiesel. Jurnal Teknik Industri, 21(1), 24-33.
Pristiyani, R., \& Kusumaningtyas, R. D. (2015). Sintesis biodiesel dan fuel bioadditive triasetin secara simultan dengan metode interesterifikasi minya jarak (Jatropha curcas). Universitas Negeri Semarang.

Purwaningrum, S. D., \& Sukaryo, S. (2018). Uji Karakteristik Biodiesel Berbahan Dasar Limbah Jeroan Ikan Diproses Menggunakan Mikrogelombang. Metana, 14(2), 37-42. https://doi.org/10.14710/metana.v14i2. 20333.

Rizkiyadi, M. E. (2008). Reaksi interesterifikasi minyak jelantah dengan metil asetat menggunakan biokatalis Candida rugosa Lipase untuk memproduksi Biodiesel. Skripsi Universitas Indonesia.

Setyahadi, S., Machsum, A. L., \& Mokodongan, R. S. (2011). Kitin sebagai Penopang untuk Amobilisasi Lipase pada Proses Trans-esterifikasi Trigliserida. 1-5.

Susilo, Bambang., Siwindarto, Ponco., Hawa, L. C. (2009). Model Kavitasi Irradiasi Gelombang Ultrasonik Pada Transesterifikasi Minyak Tanaman Menjadi Biodiesel (Issue Batch I).

Umami, V. A. (2015). Sintesis Biodiesel Dari Minyak Jelantah dengan Gelombang Mikro. In Skripsi. 